\title{
Influence of nursery sowing dates, seedling age and nitrogen levels on bulb quality and marketable yield of onion (Allium cepa L.)
}

\author{
Tayeb Muhammad ${ }^{1,2^{*}}$, Muhammad Amjad ${ }^{1}$, Sikandar Hayat ${ }^{2}$, Husain \\ Ahmad $^{2}$ and Saeed Ahmed ${ }^{3}$ \\ 1. Institute of Horticultural Sciences, Faculty of Agriculture, University of Agriculture, Faisalabad, Pakistan \\ 2. College of Horticulture, Northwest A\&F University, Yangling 712100, Shaanxi, PR China \\ 3. State University of Londrina Centre of Agriculture Sciences Londrina, Parana (PR) Brazil \\ *Corresponding author's email: tayebmuhammad@aup.edu.pk
}

Citation

Tayeb Muhammad, Muhammad Amjad, Sikandar Hayat, Husain Ahmad and Saeed Ahmed. Influence of nursery sowing dates, seedling age and nitrogen levels on bulb quality and marketable yield of onion (Allium cepa L.). Pure and Applied Biology. Vol. 5, Issue 2, 2016, pp223-233. http://dx.doi.org/10.19045/bspab.2016.50029

\begin{tabular}{llll}
\hline Received: 30/11/2015 & Revised: 10/02/2016 & Accepted: 16/02/2016 & Online First: 19/02/2016 \\
\hline \hline
\end{tabular}

\section{Abstract}

Research was conducted at Vegetable Research Area, Institute of Horticultural Sciences, University of Agriculture, Faisalabad, to study the Influence of nursery sowing dates, seedling ages and nitrogen levels on bulb quality and marketable yield of onion (Allium cepa. L) var. Pulkara. Seed of onion were sown in two different nurseries, from each nursery seedlings were transplanted at three different ages (40, 50, 60 days) and four nitrogen levels $\left(0,40,80,120 \mathrm{~kg} \mathrm{ha}^{-1}\right)$ were applied. Results revealed that sowing dates significantly affect all the parameters except splitting $\%$ and Total soluble solids (\% Brix). Seed sown on $15^{\text {th }}$ September have significantly high bulb diameter $(6.937 \mathrm{~cm})$, bulb neck diameter $(1.07 \mathrm{~cm})$, bulb fresh weight $(150.78 \mathrm{~g})$, bulb dry weight $(15.665 \mathrm{~g})$, bolting $(41.10 \%)$ and marketable yield (13.869 ton ha ${ }^{-1}$ ) while seed sown on $15^{\text {th }}$ October have significantly high bulb dry matter $(12.98 \%)$. Seedling transplanted after 50 days have high bulb diameter $(6.6838 \mathrm{~cm})$, bulb fresh weight (137.46 g), bulb dry weight (15.37 g) with medium bulb dry matter $(11.55 \%)$, bolting (29.89\%) and splitting (9.79\%). Nitrogen application also significantly affected most of the parameters. Plots treated with Nitrogen $120 \mathrm{~kg} \mathrm{ha}^{-1}$ produced maximum bulb diameter $(6.82 \mathrm{~cm})$, bulb neck diameter $(1.09 \mathrm{~cm})$, bulb fresh weight $(141.37 \mathrm{~g})$, bulb dry weight $(15.61 \mathrm{~g})$ and marketable yield (12.81 ton $\mathrm{ha}^{-1}$ ) with reducing bolting (24.72\%). Interaction between the nursery sowing dates, seedling age and nitrogen levels showed that 50 days seedling from $15^{\text {th }}$ September nursery with application of $120 \mathrm{~kg} \mathrm{~N}^{-1}$ produced maximum bulb diameter, fresh weight, dry weight and good marketable yield but increase neck diameter. 50 days seedling from $15^{\text {th }}$ September also increased the incidence of bolted bulbs which were found to be reduced by $120 \mathrm{~kg} \mathrm{ha}^{-1}$ nitrogen. It is recommended that application of $120 \mathrm{~kg} \mathrm{~N} \mathrm{ha}^{-1}$ to 50 days seedling transplanted from $15^{\text {th }}$ September nursery gave best results as compared to others in geographical area of Faisalabad-Pakistan.

Key words: Nursery; Seedling age; Nitrogen; Bulb quality; Marketable yield; Allium cepa L. 


\section{Introduction}

Onion is one of the most important commercial vegetable crop grown in Pakistan and believed to be originated in Central Asia. It is valued for its distinct pungent flavor and is an essential ingredient for the cooking in many regions. Onion is the queen of the kitchen [1]. Onion is a biennial plant, but in terms of crop production, grown as annual crop. Bulb is a storage organ and considers overwintering stage of the life cycle [2]. When bulb initiation occurs, the leaf sheaths swell and initiation of bladeless bulb scales occur. These bulb scales form the storage tissue of the bulb. As the bulb matures, two or three foliage leaf initials are produced at the base [3]. Bulbs will grow more rapidly in older plants while young plants will not initiate bulbing unless they have at least 4 leaves [4].

In Pakistan area under onion cultivation is 143.7 thousand ha with a production of 1892 thousand tones during 2010-11 [5]. Planting time varies with locality, type of onion and propagation. For early planting, seedling are raised in June and September and transplanted from July to October. In plains for winter crop, seed is sown from middle of October to end of November and transplanted in December and January. The low production of onion is mainly due to poor cultural practices, planting and harvesting time [6], method of transplant production [7] and fertilizer [8] affects the onion production.

Scientists studied different sowing time to check its effect on onion growth, maturity time, physiological disorder and yield. Faruq et al. [9] reported that among the three planting dates $\left(22^{\text {nd }}\right.$ November, $7^{\text {th }}$ December and $22^{\text {nd }}$ December) maximum bulb diameter $(5.31 \mathrm{~cm})$, bulb fresh weight (59.60 g) and bulb dry matter content was obtained from November 22 planting. Pandy et al. [10] found that neck thickness problem was more in early (June) sowing onion, similarly neck height was more in $1^{\text {st }}$ October planting (early) as compare to $15^{\text {th }}$ and $31^{\text {st }}$ October planting [11]. Jackson et al. [12] planted onion at different time from February to June and concluded that splitting problem was more in March and April plantings while in June planting problem was less. Similarly bolting was more in early planting and absent in late plantings.

In onion the use of transplants of varying age is one of cause for low yields. Currah [13] concluded that in the tropics for onion production transplanting method is more efficient and Islam [14] reported that seedlings age at transplanting time affects onion production. Transplanting date significantly affects the bolting and splitting in onions. Sweet Vidalia onion produced more seed stems (bolters) for early transplant date while less for later transplant, but splitting problem was less in early transplant and increased in later transplant [15]. Early transplanting resulted decreased in quality of onion bulb by producing thick neck bulb [16].

Nitrogen is one of the basic nutrient and important element of chlorophyll and amino acids which promotes protein content and effect growth and yield of the crop. Abdissa et al. [17] studied the effect of nitrogen on different parameters of onion and found that nitrogen application reduced bolting percentage in onion and also extended days to physiological maturity. Ghaffoor et al. [18] reported that bulb survival percentage in onion was maximum when nitrogen is applied at $150 \mathrm{~kg} \mathrm{ha}^{-1}$ but Jilani et al. [19] studied that $95.22 \%$ bulb survive at $120 \mathrm{~kg}$ $\mathrm{ha}^{-1}$ and this level is best for growth and yield of onion. The basic aim of the study was to find the best time for planting, proper transplanting age and most suitable dose of nitrogen to minimize physiological disorders in onions and get good quality bulb. 


\section{Materials and methods}

The study was conducted at Vegetable Research Area, Institute of Horticultural Sciences, University of Agriculture Faisalabad, Pakistan during the year 201112. Soils of the experimental plots were examined and were analyzed for physio chemical properties. Soil samples were randomly taken at various locations of the field at three different depths before the bed preparation and the same depths samples were mixed together to make composite samples. Soil pH ranging from 7.95 to 8.24, electrical conductivity 0.34 to $0.43 \mathrm{ds} / \mathrm{m}$, nitrogen $0.03 \%$, Phosphorous $2.14 \mathrm{ppm}$, potash $175.2 \mathrm{ppm}$ and organic matter $\%$ was 0.91(Table 1). The metrological data showed that the average season was $20.5^{\circ} \mathrm{C}$, $61.04 \%$ and $19.92 \mathrm{~mm}$ respectively. Minimum temperature $\left(10.2^{\circ} \mathrm{C}\right)$ was in the month of January while maximum in the month of May $\left(32.7^{\circ} \mathrm{C}\right)$. Highest and lowest relative humidity was in the months of May $(43.3 \%)$ and September $(75.8 \%)$. Highest rain fall was in the month of September (155.1mm).

Table 1. Soil characteristics at experimental plot

\begin{tabular}{lccc}
\hline Soil & & Soil Depth & \\
\hline Characteristic & $\mathbf{1 5 c m}$ & $\mathbf{3 0} \mathbf{~ c m}$ & $\mathbf{4 5 c m}$ \\
\hline $\mathbf{p H}$ & 8.24 & 8.2 & 7.95 \\
\hline $\mathbf{E C}(\mathbf{d s} / \mathbf{m})$ & 0.36 & 0.34 & 0.43 \\
\hline $\mathbf{N} \%$ & 0.05 & 0.03 & 0.03 \\
\hline $\mathbf{P}(\mathbf{p p m})$ & 3.03 & 2.2 & 1.2 \\
\hline K(ppm) & 175 & 174.16 & 178.3 \\
\hline $\mathbf{O . M} \%$ & 1.21 & 0.77 & 0.76 \\
\hline
\end{tabular}

The experiment was laid out in split plot design (RCBD) with three replications. Two nursery sowing dates $\left(15^{\text {th }}\right.$ September and $15^{\text {th }}$ October), three seedlings age $(40,50$, 60 days) and four nitrogen levels $(0,40,80$, $120 \mathrm{~kg} \mathrm{ha}^{-1}$ ) in the form of urea were used to study its effect on onion. Phosphorous (70 $\mathrm{kg} \mathrm{ha}{ }^{-1}$ ) and potassium (50 $\mathrm{kg} \mathrm{ha}^{-1}$ ) were applied as constant fertilizers. For nursery raising seeds were sown at $15^{\text {th }}$ September and $15^{\text {th }}$ October in lines with distance of 4 $\mathrm{cm}$ (line to line) and then covered with silt. Seedlings age was kept in main plot while the nitrogen levels as a sub plot. Seedling were transplanted to ridges $(60 \mathrm{~cm}$ wide) and planted with $10 \mathrm{~cm}$ plant to plant distance on both side of ridges. Half of nitrogen and full dose of phosphorous and potash was applied at the time of transplanting and half of the nitrogen after three weeks of transplanting. Bulbs were harvested when $80 \%$ of plants have dried most of the leaves. The leaves and roots of randomly selected plants were trimmed and bulbs were weighted in grams using electric weighing balance. The already weighed bulbs were chopped into small pieces and placed in sun for 5-7 days for partial drying. After sun drying the dried bulbs were shifted to oven and kept at $70^{\circ} \mathrm{C}$ for 48 hours to measure bulb dry weight and dry matter percentage. Bulb and neck diameter was measured at maturity by using digital Vernier Caliper in $\mathrm{mm}$ and then it was converted to $\mathrm{cm}$. Bolting and splitting \% were fined by counting bolted and splitted bulbs from each treatment and then percentage was calculated from formula. To find the marketable yield, small and unwanted bulbs were removed and yield was calculated. TSS was determined by using hand refractrometer (RHB-0-80). First the instrument was calibrated with distilled water, then a drop of juice was put on the 
prism and led was closed. Reading was noted at $20^{\circ} \mathrm{C}$ by looking towards the light through refractrometer. Collected data were analyzed using Fisher's analysis of variance (ANOVA) technique and means was compared by using DMR Test [20].

Bulb dry matter percentage $=$

Bulb dry weight (g) X 100

Bulb Fresh weight $(\mathrm{g})$

Bolting percentage $=$

Number of bolted blubs X100

Total number of bulbs

Splitting percentage $=$

Number of splitted bulbs X100

Total number of bulbs

\section{Results and discussion \\ Bulb diameter (cm)}

Analysis of data revealed that sowing dates, seedling ages and nitrogen levels have significant effect on bulb diameter while non-significant effect of all the interaction (Table 2). Plants sown on $15^{\text {th }}$ September produced large bulbs $(6.94 \mathrm{~cm})$ as compare to $15^{\text {th }}$ October. The seedlings transplanted at 50 days after sowing produced large size bulbs $(6.68 \mathrm{~cm})$ which was statistically at par with that 40 days seedling results while small size bulbs $(6.02 \mathrm{~cm})$ were produced at late transplanting age. The finding is an agreement with Zahira [21] who reported that early seeding and transplanting result in large size bulbs as compare to late. Maximum bulb diameter $(6.83 \mathrm{~cm})$ was noted when nitrogen was applied at $120 \mathrm{~kg}$ $\mathrm{ha}^{-1}$ and minimum $(6.11 \mathrm{~cm})$ was at $0 \mathrm{~kg} \mathrm{ha}^{-1}$ The results were similar with finding of [22]. Overall, onion bulbs were large in size when seed were sown in September, transplanted at 50 days and $120 \mathrm{~kg} \mathrm{ha}^{-}$ ${ }^{1}$ nitogen was applied.

\section{Bulb neck diameter (cm)}

Neck diameter is an important character in onion because it indicates storage ability.
Thin neck diameter bulbs store better as compare to thick neck diameter. Data obtained for bulb neck diameter revealed that neck thickness was significantly affected by sowing dates, nitrogen levels and interaction of sowing dates and seedling age while non-significant results was showed by seedling age and other interactions (Table 2). Results show that maximum neck diameter $(1.16 \mathrm{~cm})$ was found in bulbs that were sown on $15^{\text {th }}$ September and minimum $(0.97 \mathrm{~cm})$ in $15^{\text {th }}$ October sowing. The result was similar to Pandy et al. [10] who found greater neck thickness to early sowing as compare to later. Comparing the mean table for nitrogen it was evident that $120 \mathrm{~kg} \mathrm{ha}^{-1}$ nitrogen gave the maximum $(1.09 \mathrm{~cm})$ neck diameter while minimum $(0.95 \mathrm{~cm})$ was at $0 \mathrm{~kg} \mathrm{ha}^{-1}$ nitrogen. The results were similar to the Jilani [23] who reported that increasing nitrogen fertilization results thick necks of onion bulb. The interaction between sowing dates and seedling age shows that with the increase of seedling size the neck diameter was also increased while an opposite phenomena was observed in later sowing dates (Figure 1). Maximum neck thickness was found when seed was sown on $15^{\text {th }}$ September and transplanted after 60 days and minimum was for $15^{\text {th }}$ October of same size seedling. The reason was neck develops from base of leaves and its diameter depends on number and complete drying of the leaves at maturity. In first sowing entire seedling type produced more leaves but time for complete drying of leaves base for 60 days was less and in case of second sowing date the old age seedling produced less number of leaves. Therefore the neck diameter varies among the seedling of sowing dates. 
Table 2. Onion bulb diameter $(\mathrm{cm})$, neck diameter $(\mathrm{cm})$, bulb fresh weight $(\mathrm{g})$, bulb dry weight and bulb dry matter \% affected by sowing dates, seedling age and nitrogen levels

\begin{tabular}{|c|c|c|c|c|c|}
\hline Treatment & $\begin{array}{l}\text { Bulb Diameter } \\
(\mathrm{cm})\end{array}$ & $\begin{array}{l}\text { Neck Diameter } \\
(\mathrm{cm})\end{array}$ & $\begin{array}{c}\text { Bulb fresh } \\
\text { weight (g) }\end{array}$ & $\begin{array}{l}\text { Bulb dry } \\
\text { weight (g) }\end{array}$ & $\begin{array}{ll}\text { Bulb dry } \\
\text { matter\% }\end{array}$ \\
\hline \multicolumn{6}{|c|}{ Sowing Dates (D) } \\
\hline 15-Sep & $6.9375 a$ & $1.0763 \mathrm{a}$ & $150.78 \mathrm{a}$ & $15.665 \mathrm{a}$ & $10.526 b$ \\
\hline $15-$ Oct & $5.9428 b$ & $0.9792 b$ & $100.47 \mathrm{~b}$ & $12.851 \mathrm{~b}$ & $12.987 \mathrm{a}$ \\
\hline \multicolumn{6}{|c|}{ Seedling Age (A) } \\
\hline 40 days & $6.6127 a$ & 1.0434 & $132.76 a$ & $14.890 \mathrm{a}$ & $11.430 \mathrm{~b}$ \\
\hline 50 days & $6.6838 \mathrm{a}$ & 1.0389 & $137.46 \mathrm{a}$ & $15.375 \mathrm{a}$ & $11.556 \mathrm{~b}$ \\
\hline 60 days & $6.0240 \mathrm{~b}$ & 1.0434 & $106.65 b$ & $12.509 \mathrm{~b}$ & $12.283 \mathrm{a}$ \\
\hline \multicolumn{6}{|c|}{ Nitrogen $\left(\mathrm{kg} \mathrm{ha}^{-1}\right) \mathrm{N}$} \\
\hline 0 & $6.1115 c$ & $0.9593 b$ & $108.58 \mathrm{c}$ & $12.285 \mathrm{c}$ & 11.602 \\
\hline 40 & $6.3507 b$ & $1.0243 \mathrm{ab}$ & $121.76 b$ & $14.185 b$ & 12.021 \\
\hline 80 & $6.4733 b$ & $1.0315 \mathrm{ab}$ & $130.78 \mathrm{ab}$ & $14.945 \mathrm{ab}$ & 11.852 \\
\hline 120 & $6.8251 \mathrm{a}$ & $1.0960 \mathrm{a}$ & $141.37 \mathrm{a}$ & $15.617 \mathrm{a}$ & 11.551 \\
\hline \multicolumn{6}{|l|}{ Interaction } \\
\hline $\mathrm{D} \times \mathrm{A}$ & ns & $*$ & ns & ns & ns \\
\hline $\mathrm{D} \times \mathrm{N}$ & ns & ns & $*$ & ns & $*$ \\
\hline$A \times N$ & ns & ns & ns & ns & ns \\
\hline $\mathrm{D} \times \mathrm{A} \times \mathrm{N}$ & ns & ns & ns & $\mathrm{ns}$ & ns \\
\hline
\end{tabular}

Means in the same category followed by different letters are significantly different at

$\mathrm{P} \leq 0.05$ levels. $\mathrm{ns}=$ non-significant

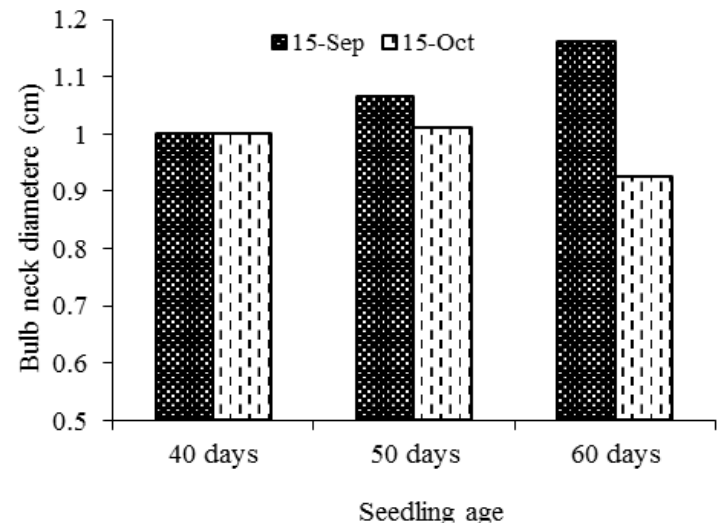

Figure 1. Bulb neck diameter affected by sowing dates and seedling ages

\section{Bulb Fresh Weight}

Maximum (150.78 g) bulb fresh weight was obtained from plants that were sown on $15^{\text {th }}$ September and minimum (100.47 g) from $15^{\text {th }}$ October sowing. Seedling transplanted after 50 days of sowing produced heavy bulbs (137.46 g) as compare to 40 and 60 days. From results it was observed that bulb from medium size seedling gain maximum weight than small and larger seedling. Kanton et al. [24] concluded the significant effect of transplanting age on the bulb fresh weight. Study on nitrogen show that maximum $(141.37 \mathrm{~g})$ bulb fresh weight was obtained by applying nitrogen at the rate of $120 \mathrm{~kg} \mathrm{ha}^{-1}$ and minimum (108.58 g) was from zero nitrogen. The result was similar to finding of Khan et al. [25] who evaluated that increasing the nitrogen level resulted in the increased onion bulbs weight. The combine effect of sowing dates and nitrogen level shows that crop planted on $15^{\text {th }}$ September with application $120 \mathrm{~kg} \mathrm{ha}^{-1} \mathrm{~N}$ produced maximum $(175.04 \mathrm{~g})$ bulb fresh weight as compared other sowing date and nitrogen application (Figure 2).

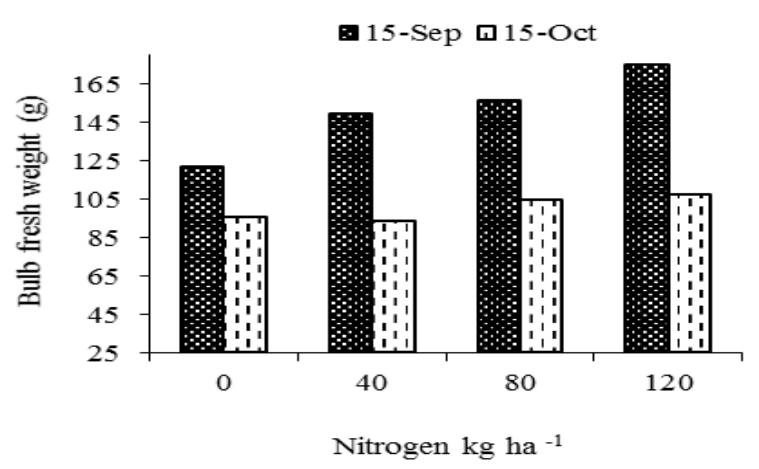

Figure 2. Bulb fresh weight affected by sowing dates and nitrogen levels 


\section{Bulb dry weight (g)}

Mean values show significant results for sowing dates, seedling ages and nitrogen application but non-significant results for interaction. Maximum (15.66 g) bulb dry weight was recorded when seed were sown on $15^{\text {th }}$ September and minimum $(12.85 \mathrm{~g})$ for $15^{\text {th }}$ October sowing. In case of seedlings age highest value $(15.37 \mathrm{~g})$ was obtained for 50 days transplants and lowest value (12.50 g) for 60 days transplants. This must be due to that medium size seedling produced larger bulb which results in maximum dry weight. The results are in line with Singh and Singh [26] who described that early sowing and 7 weeks old seedlings have significantly higher dry weight. Study on nitrogen shows that maximum $(15.61 \mathrm{~g})$ bulb dry weight was obtained by applying nitrogen at the rate of $120 \mathrm{~kg} \mathrm{ha}^{-1}$ and minimum (12.28 g) were from no application of nitrogen. Nitrogen application increased bulb fresh weight in return bulb dry weight also increased. Similar result was reported that nitrogen fertilization significantly affects bulb dry weight and maximum dry weight was obtained by application of $115 \mathrm{~kg} \mathrm{ha}^{-1}$ nitrogen [17].

\section{Bulb Dry Matter \%}

Mean value illustrate significant results for sowing dates, seedling age and interaction of sowing dates and nitrogen while nonsignificant results for nitrogen and other interaction. Bulb dry matter percentage was maximum $(12.98 \%)$ when seeds were sown on $15^{\text {th }}$ October and minimum $(10.52 \%)$ in $15^{\text {th }}$ September sowing. The seedling transplanted after 60 days have high (12.28\%) dry matter percentage as compared to the seedling transplant in early stage. The results indicated that as the bulb size decreased quantity of water contents also decreased that result in high percentage of dry matter. So, early sowing date produced large size bulb having low dry matter percentage as compare to late sowing.
Interaction of sowing dates and nitrogen shows that when seeds were sown at $15^{\text {th }}$ October and $80 \mathrm{~kg} \mathrm{ha}^{-1}$ nitrogen was applied bulbs gain high $(13.41 \%)$ dry matter percentage as compared to other application (Figure 3). The result shows that main factor of dry matter was sowing dates while high nitrogen doze mainly maintain proper growth of plant and no direct role in the dry matter contents. Woldetsadik \& Workneh [27] reported that nitrogen applications have no significant effect on the dry matter content of bulb (Table 3).

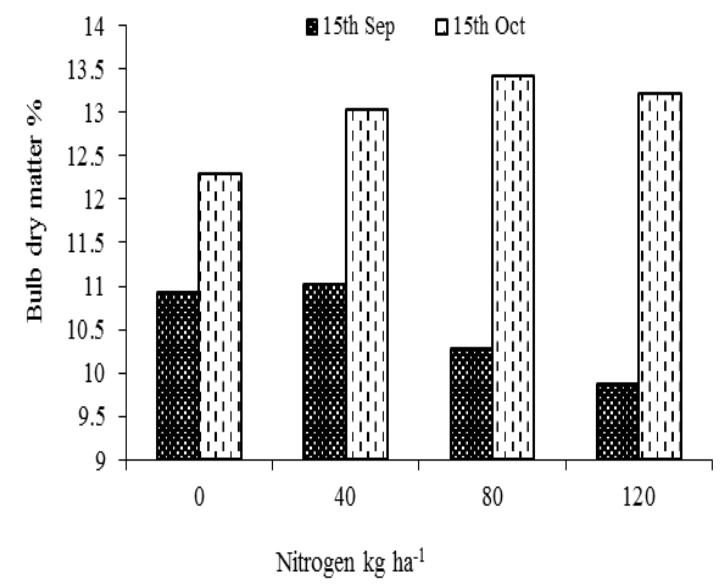

Figure 3. Bulb dry matter \% affected by sowing dates and nitrogen levels

\section{Bolting \%}

Maximum bolting percentage (41.10\%) was recorded when nursery was raised on $15^{\text {th }}$ September as compare to $15^{\text {th }}$ October. These results are in line with those of Khokhar et al. [28] who reported that seed sown in September produced more bolted bulbs than other sowing dates. Seedlings transplanted early have more $(33.52 \%)$ bolting percentage than medium and late transplanting. Similar result was obtained by Boyhan et al. [15] who found that early transplants produced more bolters as compared to late. Effect of nitrogen shows that maximum bolting (36.36\%) was found in plants with zero application of nitrogen while minimum $(24.72 \%)$ at $120 \mathrm{~kg} \mathrm{ha}^{-1}$ 
nitrogen. Result was similar to Yamasaki and Tanaka [29] who reported that low nitrogen promoted bolting in onion plants. Among interaction of sowing dates and seedling age, maximum bolting percentage $(41.85 \%)$ was recorded when nursery was raised on $15^{\text {th }}$ September and transplanted after 40 days while minimum $(9.65 \%)$ was in 60 days seedling of $15^{\text {th }}$ October sowing (Figure 4). In both sowing dates as seedling age increased problem of bolting decreased but the effect was clear in late sowing. Sowing dates and nitrogen interaction shows that no application of nitrogen to early sowing dates cause maximum $(52.27 \%)$ problem of bolting as compared to high nitrogen and late sowing (Figure 5).

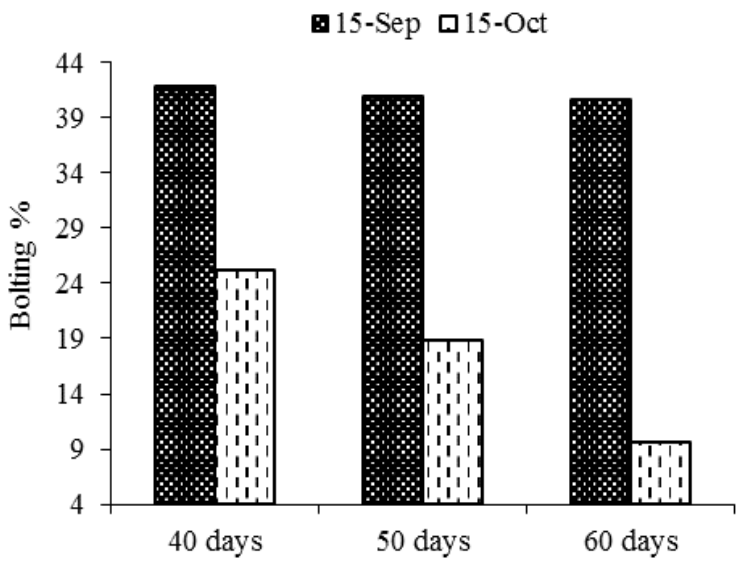

Figure 4. Bolting \% affected by sowing dates and seedling age

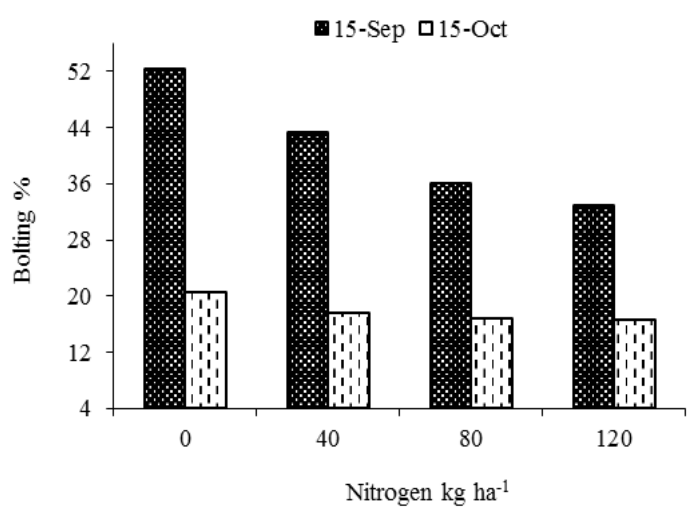

Figure 5. Bolting \% affected by sowing dates and nitrogen levels

\section{Splitting \%}

Splitting percentage was significantly influence by seedling age, as the seedling age increased number of split bulbs reduced. Maximum (12.97\%) splitting percentage was recorded in 40 days seedling while minimum (7.481\%) was in 60 days seedling. Nourai [30] also reported that high incidence of splits was occur in early transplanted onion as compared to the late transplanted. Sowing dates and seedling age interaction shows that maximum split bulbs $(15.53 \%)$ were formed when seed were sown on $15^{\text {th }}$ September and transplanted after 40 days, while minimum $(5.11 \%)$ were when seed sown on $15^{\text {th }}$ September and transplanted after 60 days (Fig. 6). It was observed that in both sowing dates the late seedling have minimum problem of splits bulbs as compared to early.

\section{Total soluble solids (\% Brix)}

Sowing dates, seedling age, nitrogen and interaction of all these factors have no significant affect on total soluble solid of onion bulbs. This may be due that TSS percentage mainly influence by cultivar and sulfur amount not these experimental factors. Leilah et al. [31] found that total soluble solid difference was not reached to the significant level among different seedling age and similarly Woldetsadik \& Workneh [27] also reported non-significant effect of nitrogen on total soluble solids of onion.

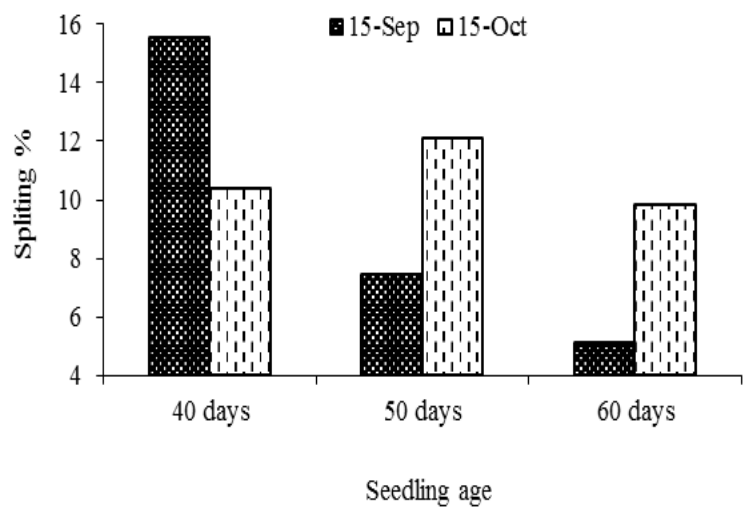

Figure 6. Splitting \% affected by sowing dates and seedling age 
Table 3. Bolting \%, splitting \%, Tss and marketable yield of onion as affected by sowing dates, seedling age and nitrogen levels

\begin{tabular}{|c|c|c|c|c|}
\hline Treatment & Bolting \% & Spliting \% & Tss (\% Brix) & $\begin{array}{l}\text { Marketable yield } \\
\text { ton } \mathrm{ha}^{-1}\end{array}$ \\
\hline \multicolumn{5}{|c|}{ Sowing Dates (D) } \\
\hline 15-Sep & $41.104 \mathrm{a}$ & 9.371 & 9.9182 & $13.869 \mathrm{a}$ \\
\hline 15 -Oct & $17.903 b$ & 10.795 & 9.2682 & $9.079 \mathrm{~b}$ \\
\hline \multicolumn{5}{|c|}{ Seedling Age (A) } \\
\hline 40 days & $33.522 \mathrm{a}$ & $12.973 \mathrm{a}$ & 9.593 & $11.725 b$ \\
\hline 50 days & $29.897 b$ & $9.795 b$ & 10.007 & $12.720 \mathrm{a}$ \\
\hline 60 days & $25.092 \mathrm{c}$ & $7.481 \mathrm{c}$ & 9.180 & $9.978 \mathrm{c}$ \\
\hline \multicolumn{5}{|c|}{ Nitrogen $\left(\mathrm{kg} \mathrm{ha}^{-1}\right) \mathbf{N}$} \\
\hline 0 & $36.363 a$ & 8.641 & 9.383 & $10.037 \mathrm{c}$ \\
\hline 40 & $30.482 \mathrm{~b}$ & 9.469 & 9.287 & $11.141 \mathrm{~b}$ \\
\hline 80 & $26.449 \mathrm{c}$ & 11.111 & 10.277 & $11.901 \mathrm{ab}$ \\
\hline 120 & $24.721 \mathrm{c}$ & 11.111 & 9.426 & $12.818 \mathrm{a}$ \\
\hline \multicolumn{5}{|l|}{ Interaction } \\
\hline $\mathrm{D} \times \mathrm{A}$ & * & $*$ & ns & $*$ \\
\hline $\mathrm{D} \times \mathrm{N}$ & * & ns & ns & $\mathrm{ns}$ \\
\hline $\mathrm{A} x \mathrm{~N}$ & ns & ns & ns & $*$ \\
\hline $\mathrm{D} \times \mathrm{A} \times \mathrm{N}$ & $\mathrm{ns}$ & $\mathrm{ns}$ & $\mathrm{ns}$ & $\mathrm{ns}$ \\
\hline
\end{tabular}

Means in the same category followed by different letters are significantly different at $\mathrm{P} \leq 0.05$ levels. $\mathrm{ns}=$ non-significant

Marketable yield (ton ha-1)

Data recorded for marketable yield shows result for all the factors and interaction of seedling age with sowing dates and nitrogen. It is evident that high marketable yield (15.51 tons) was obtained from plants sown on $15^{\text {th }}$ September and transplanted after 50 days and minimum (6.96 tons) from 60 days seedling of $15^{\text {th }}$ October sowing (Figure7). The marketable yield of 40 days seedling of September nursery was reduced due high cull percentage while in October nursery as the seedling age increase the marketable yield decrease due low yield and large number of small non marketable bulbs. September sowing gave high (13.86 tons) marketable yield as compare to October sowing. The results are in line with those of Khokhar et al, [28] who reported that significant high marketable yield of onion can be obtained when plants sown in September and translated at proper seedling age. Data regarding nitrogen higher marketable yield (12.81 tons) was from 120 $\mathrm{kg} \mathrm{ha}^{-1}$ and minimum (10.03 tons) was from control. Marketable yield gradually increased as the amount of nitrogen increased. Result was in accordance with the finding of Maier et al, [32] who reported that marketable yield was significantly increased as the rate of nitrogen increased. In case of seedling age and nitrogen interaction maximum (13.924 tons) marketable yield was obtained from application of $120 \mathrm{~kg} \mathrm{ha}^{-1}$ nitrogen to 50 days seedling and minimum (8.210 tons) from 60 days seedling with no nitrogen application (Figure 8).

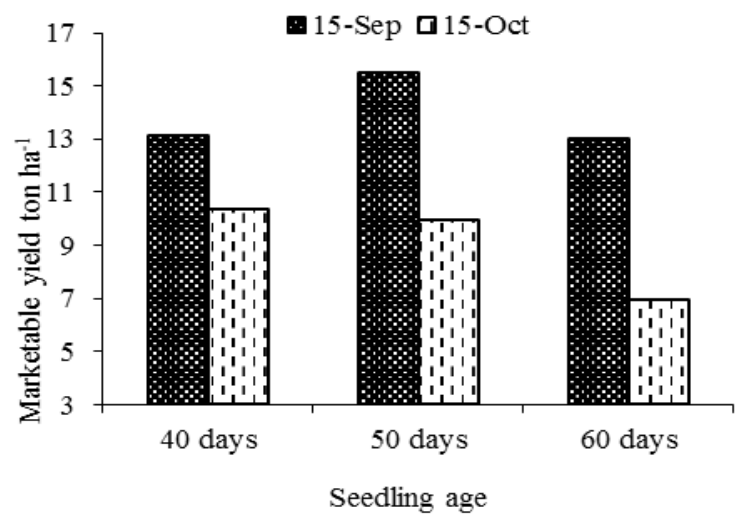

Figure 7. Marketable yield (ton ha $\mathbf{h a}^{-1}$ ) affected by sowing dates and seedling age 


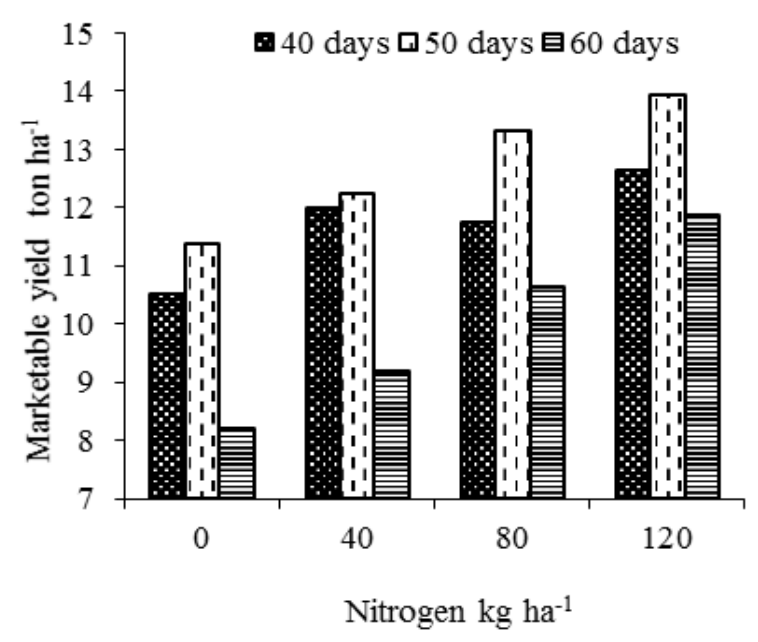

Figure 8. Marketable yield (ton ha ${ }^{-1}$ ) affected by seedling age and nitrogen levels

\section{Conclusion}

Nursery sowing time, age of transplanting seedling and nitrogen levels have important role in overcoming physiological disorder in onion. Early nursery sowing and normal size seedling produce good size bulbs but having more bolting problem. 50 days old seedlings from 15 September nursery with application of $120 \mathrm{~kg} \mathrm{ha}^{-1}$ produced more marketable yield and high nitrogen level also reduce the chance of bolting without any role in splitting.

\section{Authors' contributions}

Conceived and designed the experiments: $\mathrm{T}$ Muhammad \& M Amjad, Performed the experiments: $\mathrm{T}$ Muhammad, Analyzed the data: T Muhammad \& S Hayat, Contributed reagents/ materials/ analysis tools: $\mathrm{T}$ Muhammad H Ahmad \& S Ahmad, Wrote the paper: T Muhammad.

\section{Acknowledgment}

We would like to extend our thankfulness to the staff of vegetable seed production lab, Institute of Horticultural Sciences University of Agriculture Faisalabad for providing research inputs.

\section{References}

1. Selvaraj S (1976). Onion: Queen of the kitchen. Kisan World 3(12): 32-34.
2. Lancaster JE \& Boland MJ (1990). Flavor biochemistry, food science and minor crops. In: Onions and Allied crops, (Ed. J.L Brewster and H.D Rabinowitch). CRC Press Baco Ratani Florida 3: 3372

3. Brewster JL (1990). Physiology of crop growth and bulbing. In: Onion and Allied crops, (Ed. H.D. Rabinowitch and J.L. Brewster). CRC Press Baco Ratani Florid 1: 53-88.

4. Sobeih WY \& Wright CJ (1986). The photoperiodic regulation of bulbing in onions (Allium cepaL.). 2. Effects of plant-age and size. J Hortic Sci 61(3): 337-342.

5. MINFA (2011). Ecnomic Survey of Pakistan. Federal Bureau of Statistics 2010-2011. Ministry of Food and Agriculture (Economic Wing), Government of Pakistan, Islamabad.

6. Galmarini CR \& Gaspero D (1995). Effect of transplanting date and plant density on yield responses on onion (Valenciana type). J Hortic Argentina 14(37): 23-29.

7. Russo VM (2004). Greenhouse-grown transplants as an alternative to bare-root transplants for onions. Hort Sci 39(6): 1267-1271.

8. Sharma RP, Datt N \& Sharma PK (2003). Combined application of nitrogen, phosphorus, potassium and farmyard manure in onion (Allium cepa L.) under high hills, dry temperate conditions of north-western Himalayas. Indian $J$ Agric Sci 73: 225-227.

9. Faruq MO, Alam MS, Rahman M, Alam MS \& Sharf uddin AFM (2003). Growth, yield and storage performance of onion as influenced by planting time and storage condition. Pak J Biol Sci 6(13): 1179-1182.

10. Pandy VB, Qadri SMH, Chongule AB \& Tripathi BP (1992). The effect of time of sowing on yield and quality of small 
onion (Allium cepa L.). Newsletter Associated Agricultural Development Foundation 12: 1-2.

11. Derawadan, Ali S, Tahir M, Majeed A \& Khan A (2002). Date of sowing and genotype interaction effect on the bulb yield of transplanted onion (Allium cepaL.). J Plant Sci 1(6): 675-677.

12. Jackson K, Duff AA \& O'Donnell WE (2001). Development of a suite of onion varieties for the subtropical region of the Lockyer valley in S.E. Queensland, Australia. Acta Hort 555: 239-242.

13. Currah L (1990). Onion in tropical regions. In: Onion Newsletter for the Tropics. (Ed. F.J. Proctor).Chatham, UK. Natural Resources Institute, 232.

14. Islam MJ (1981). An investigation into the effect of date of planting and age of seedling for a late crop of onion. M.Sc. Thesis. Dept. of Horticulture, Univ. of Mymensingh, Bangladesh.

15. Boyhan GE, Torrance RL, Cook J, Riner C \& Hill CR (2009). Sowing date, transplanting date and variety effect on transplanted short-day onion production. Hort Technol 19(1): 66-71.

16. Mostafa AK (1998). Yield and qualities of Giza 20 onion bulb as affected by transplanting date and source of seed. $J$ Agric Sci 23(1): 61- 69.

17. Abdissa $\mathrm{Y}$, Tekalign $\mathrm{T} \&$ Pant $\mathrm{LM}$ (2011). Growth, bulb yield and quality of onion (Allium cepa L.) as influenced by nitrogen and phosphorus fertilization on vertisol I. growth attributes, biomass production and bulb yield. African $J$ Agric Res 6(14): 3252-3258.

18. Ghaffoor A, Jilani MS, Khaliq G \& Waseem K (2003). Effect of different NPK levels on the growth and yield of three onion varieties. Asian J Plant Sci 2: 342-346.

19. Jilani MS, Ghaffoor A, Waseem K \& Farooqi JI (2004). Effect of different levels of nitrogen on growth and yield of three onion varieties. Int J Agric Biol 6(3): 507-510.

20. Petersen RG (1994). Agricultural Field Experiments Design and Analysis. Marcel and Dekker, New York.

21. Zahira MA (1999). Effect of onion transplanting date and inter-cropping pattern on cotton-onion association. $J$ Agric Sci Mansoura Univ 24(3): 899909.

22. Aliyu U, Dikko AU, Magaji MD \& Singh A (2008). Nitrogen and intra-row spacing effect on growth and yield of onion (Allium cepa L.). J Plant Sci 3(3): 188-193.

23. Jilani MS (2004). Studies on the management strategies for bulb and seed production of different cultivars of onion (Allium cepaL.). Ph.D. Thesis, p.91 Gomal University, Dera Ismail Khan. Pakistan.

24. Kanton RAL, Abbey L, Hilla RG, Tahil MA \& Jan ND (2002). Influence of transplanting age on bulb yield and yield components on onion (Allium cepaL.). J Veg Crop Prod 8(2): 27-37.

25. Khan AA, Zubair M, Bari A \& Maula F (2007). Response of onion (Allium cepa L.) growth and yield to different levels of nitrogen and zinc in Swat valley. Sarhad J Agric 23(4): 933-936.

26. Singh DP \& Singh RP (1974). Studies on the effect of time of sowing and age of seedlings on growth and yield of onion (Allium cepa L.). Indian J Hortic 31(1): 69-73.

27. Woldetsadik SK \& Workneh TS (2010). Effects of nitrogen levels, harvesting time and curing on quality of shallot bulb. African J Agric Res 5(24): 33423353.

28. Khokhar KM, Hidayatullah, Mahmood T, Hussain SI, Bhatti MH \& Laghari MH (2002). Effect of seedling/set sizes and planting times on bulb yield and quality in onion cultivar Phulkara 
during autumn. J Plant Sci 1(6): 665667.

29. Yamasaki A \& Tanaka K (2005). Effect of nitrogen on bolting of bunching onion (Allium fistulosum L.). Hort Res Japan 4(1): 51-54.

30. Nourai AH (2006). Effects of transplanting date, nitrogen nutrition and watering regime on yield, quality and storage of the red onion, p. 186196. In: K. El-Siddig (ed). Proceeding the $37^{\text {th }}$ and $38^{\text {th }}$ meetings of the
National Crop Husbandry Committee, Wad Medani-Sudan.

31. Leilah AA, El-Kalla SA, Mostafa AK \& Afifi HMA (2003). Performance of some local Egyptian onions strains under different planting dates. Sci J of King Faisal Univ 4(1): 119-136.

32. Maier NA, Dahlenburg AP \& Twigden TK (1990). Effect of nitrogen on the yield and quality of irrigated onions (Allium cepa L.) cv. Cream Gold grown on siliceous sands. Australian J Expe Agric 30(6): 845-851. 